\title{
Literacy practices in co-taught early years classrooms. Study protocol: The seaside case
}

\author{
Åse Kari Hansen Wagner, Atle Skaftun \& Erin McTigue \\ University of Stavanger
}

\begin{abstract}
The present protocol describes the background, theoretical framework and methods for a qualitative study of co-taught, Norwegian, L1 classrooms-The Seaside case. The participants are six classes and their teachers from six different schools in the Seaside municipality. All classes had one extra teacher in all 8 L1 Norwegian lessons each week, in Year One and Year Two. Co-teaching provides pedagogic potential and flexibility and can enhance students' learning. However, evidence from teacher-student ratio research is inconsistent across contexts (Solheim et al., 2017; Solheim \& Opheim, 2018), and there is also a need for studies exploring connections specifically in the Norwegian school context. Our overarching research questions are: (1) What characterizes literacy practices in L1 initial co-taught literacy lessons? (2) How is the extra teacher resource utilized in L1 initial co-taught literacy lessons, and what characterizes interaction, patterns of discourse, organization and roles in the classroom (teachers and students)? (3) What are the students' conditions for participation, engagement and dialogue in L1 initial co-taught literacy lessons?
\end{abstract}

Keywords: case-study; co-teaching; teacher-student ratio; early literacy education and practices; student participation

Responsible editor: Marte Blikstad-Balas

Received: February, 2020; Accepted: October, 2020; Published: January, 2021

\section{Introduction}

Teacher-student ratio is often noted as a structural constraint supporting the status quo and limiting that which is feasibly possible to achieve in the classroom. It could seem evident that a higher teacher-student ratio, or smaller classes, would serve to remove such a constraint and thereby be an important contextual condition for promoting student learning through increased interaction, engagement and differentiation within the classroom. However, it is unclear whether increased teacherstudent density itself actually promotes a higher quality of the learning, as evidence

^Correspondence: Åse Kari Hansen Wagner, e-mail: aase-kari.h.wagner@uis.no

(C) 2020 Åse Kari Hansen Wagner, Atle Skaftun \& Erin McTigue. This is an Open Access article distributed under the terms of the Creative Commons Attribution 4.0 International License (https://creativecommons.org/licenses/by$\mathrm{nc} / 4.0 /$ ), allowing third parties to copy and redistribute the material in any medium or format and to remix, transform, and build upon the material for any purpose, even commercially, provided the original work is properly cited and states its license. 
from research is inconsistent (Solheim et al., 2017; Solheim \& Opheim, 2018). Such mixed outcomes provide an impetus for the design of this research.

The Seaside case was originally designed to provide observational data, from real life classrooms, as a point of reference in the overall work of understanding the results from a large RCT investigating the individual and complementary effects of a higher teacher-student ratio and professional development for teachers in L1 initial literacy education (Two Teachers in the Class, Solheim et al., 2017) (see Appendix 1 for more information on the RCT). Above and beyond the complementary benefits of the case to the RCT's quantitative analysis, the case holds great value in itself, as a comprehensive qualitative study of teaching practices in Norwegian L1 classrooms. The timing of this research is particularly relevant because educational policy and curricula increasingly emphasize students' active learning and other progressive ideas about education, without necessarily having extensive and systematic insight into the process and everyday life in Norwegian classrooms. An important shift in the conditions for our study, was a new norm for teacher-student ratio implemented for Norwegian schools in autumn 2018, stating that there should be a maximum of 15 students per teacher from Year One through Year Four. This policy adds relevance to this work, as more than one teacher in L1 lessons would be more of a normal situation after the implementation of the new norm.

In the Seaside case we specifically study literacy practices in six primary school classrooms where there are two teachers present in the L1 subject. Research on literacy practices in early literacy education is scarce in the Norwegian context. Internationally, the research focus places much emphasis on teacher expertise (e.g. Hall, 2012) and effectiveness (e.g. Hall, 2012; Goigoux et al., 2016), but relatively little emphasis on the extended early literacy practice in itself. The Seaside case allows for research in a variety of areas (e.g., writing, oracy, guided reading) which is connected through a shared theoretical grounding. Specifically, we see practice as a social and cultural space for interaction and learning, consisting of a set of key elementsparticipants, actions, setting in time and space, and artefacts. Rooted in a sociocultural understanding of language, learning and literacy, our approach also implies a focus on student participation and dialogic aspects of that which happens in the observed classrooms.

Our overarching research questions are as follows:

1) What characterizes literacy practices in L1 initial co-taught literacy lessons?

2) How is the extra teacher resource utilized in L1 initial co-taught literacy lessons, and what characterizes interaction, patterns of discourse, organization and roles in the classroom (teachers and students)?

3) What are the students' conditions for participation, engagement and dialogue in L1 initial co-taught literacy lessons?

These research questions will be answered through various scientific works detailed below (see Methods for analyses and Dissemination). 


\section{A. K. H.Wagner, A. Skaftun \& E. McTigue}

\section{Background}

\section{The Norwegian school context}

In Norway, most children attend kindergarten (one-five years) full time. The Norwegian kindergarten builds on a sociocultural approach emphasizing overall learning (The Norwegian Directorate for Education and Training, 2017), where the attitude is child-centred and founded on values such as care and development, play and relationships, and children's participation. There are no strict boundaries between informal and formal learning situations, and the kindergarten teacher will, to a large extent, allow informal child-initiated activities to be the starting points for learning situations, on children's premises. This approach differs from the far more subject and outcome-oriented Early Education tradition found in many other countries.

Norwegian children start formal school in August of the calendar year in which they turn six and attend primary school for seven years. Norwegian school is free and inclusive, with a strong focus on alleviating social differences. There are no grades in primary school, only formative assessments, and competence goals appear in the syllabus only after Year Two. There are few alternative programs and no streaming or tracking. Norway has a centralized curriculum (The Norwegian Directorate for Education and Training, 2018), but allows considerable freedom for local schools and teachers to make their own decisions regarding organization and instructional methods. Even if literacy education is integrated in all subjects, the curriculum ascribes a particular responsibility to the L1 Norwegian subject.

\section{Educational policy and reality}

Teachers, school leaders, politicians and scientists often share an ideal of committed students who solve relevant problems (in all subjects) and apply knowledge when facing new situations and new problems (Ludvigsen et al., 2015; Pellegrino \& Hilton, 2013). Norwegian schools are facing the implementation of a new curriculum autumn 2020, Fagfornyelsen, ${ }^{1}$ (The Renewal of the disciplines) in which ideas like these are prominent. It is easy to agree that this form of in-depth and active learning should be central to school. However, many roadblocks can appear between the current status of schools and the realization of this bold vision.

Specifically, despite a relatively strong focus on student participation in current Norwegian curricula, it seems reasonable to say that "traditional practice" (Cazden, 2001; Goodlad, 2004; Hicks, 1996) prevails in Norwegian schools. For example, Hodgson et al. (2012) found that $62 \%$ of lessons were spent on whole class teaching, and that these whole class sessions were characterized by a lack of instructional depth. Another typical feature of whole class teaching is that it is dominated by the teacher, both structurally and quantitatively. Teachers normally

\footnotetext{
${ }^{1}$ https://www.udir.no/laring-og-trivsel/lareplanverket/fagfornyelsen/
} 
talk $2 / 3$ of the time (cf. the " $2 / 3$ rule", Klette, 2003), thus crowding out student voices.

Structurally, form and content support each other, often manifesting in an IRE-structure (teacher Initiation - student Response - teacher Evaluation). IRE, or variants of it, provides students and teachers with predetermined roles to play in the classroom practice. The dramaturgic structure of the IRE clearly serves a function and might also be seen as a precondition for teaching a class of 20-30 students. Over several decades, however, research has also emphasized how this form may limit the opportunity space for meaningful participation, and thus in itself inhibit substantive engagement, and at best making space for procedural engagement (Nystrand \& Gamoran, 1991).

Traditional practice along with the IRE structure in classroom interaction seems highly resistant to change (Alexander, 2008; Lefstein, 2008; Segal \& Lefstein, 2016; WIlkinson et al., 2017). As curricular reforms continue to elaborate an image of problem-based education, critical thinking, in-depth learning and an overall image of students participating in the production of knowledge, we might fear an increasing gap between policy and real-life practices. Furthermore, digital resources are increasingly available in Norwegian classrooms, providing teachers and students with new dialogic spaces (Wegerif, 2013), as well as an enhancement of existing ones. But some researchers have found unintended effects towards the opposite-that students increasingly work alone and in isolation (Gilje et al., 2020; Slotte, 2019), thus replicating the traditional practice in a modern media. Yet, when considering literacy teaching practice specifically, the need for students to orally practice in different discourses, write across genres and apply new vocabulary is particularly central to their development. In total, these trends of traditional practice are troubling due to the importance of interaction between teachers and students in the literacy classroom and the motivation behind increased teacherstudent ratios.

\section{Teacher-student ratio}

In general, a higher teacher-student ratio provides possibilities for early literacy practice. A higher teacher-student ratio can enhance more individual attention (Blatchford et al., 2007) and higher engagement in learning activities (Bressoux, 2016), resulting in improved student progress. One way of increasing the teacher-student ratio is co-teaching (Solheim \& Opheim, 2018). Several benefits of co-teaching have been emphasized. Some research indicates that co-teaching leads to higher academic learning for students with disabilities, language delays, and emotional risks (Friend \& Barron, 2016; Mackey et al., 2018). Positive learning outcomes have also been reported for second language students (Mackey et al., 2018) and gifted students (Hughes \& Murawski, 2001). Further, co-teaching environments are reported to improve students' social interactions and collaboration, for students with and without special needs (Villa et al., 2013; Walsh, 2012). However, not all research points to 


\section{A. K. H.Wagner, A. Skaftun \& E. McTigue}

the benefits of co-teaching, neither concerning student outcomes (Friend \& Barron, 2016; Murawski \& Swanson, 2001), nor when it comes to teachers' experiences (Carty \& Farrell, 2018). Succeeding with co-teaching also depends on how teachers co-plan (Brown et al., 2013), as well as their forms of cooperation in the classroom. It seems that students benefit more from types of teacher collaboration that involve and exploit the expertise of both teachers (Wexler et al., 2018). Summing up, co-teaching provides pedagogic potential and flexibility, but is no guarantee for better student learning.

The organizational structure of co-teaching (and the extent to which it allows each teacher to draw upon their strengths) may contribute to its success and student outcomes. Friend, et al. (2010, p. 12) describe six potential forms of teacher collaboration: (1) One teach, one observe, where one teacher leads large-group instruction while the other collects academic, behavioural, or social data on specific students or the class as a whole; (2) Station teaching, where groups of students rotate from station to station, and are taught by the teachers at two stations, while working independently at the third; (3) Parallel teaching, where the two teachers split the class in two equal parts, and present the same material for both. The goal here would be increased differentiation and student participation; (4) Alternative teaching, where one teacher works with most students while the other teacher works with a small group; (5) Teaming, where both teachers lead large-group instruction, and both of them lecture, represent different views in a debate or illustrating two ways to solve a problem, and (6) One teach, one assist, where one teacher leads instruction while the other circulates among the students offering individual assistance.

Yet, in previous studies regarding teacher collaboration, despite the numerous options for collaboration, Alexander (1997) reported that many teachers found it difficult to work alongside another, and preferred to work with separate groups, independently and/or physically separated. Also, the designated classroom teacher would often struggle with sharing territory and ownership with another teacher, whereas the second teacher would struggle with a feeling of not getting access. One can assume that the different forms of teacher collaboration (and potential levels of conflict) will influence possibilities for student participation and learning.

Ideally, being two teachers in early literacy education can allow more time for small group guided reading and writing activities, more differentiation in text choices offered, or individualized reading and writing lessons for different groups of students. The additional teacher could also give room for engaging dialogues on texts, and for talk, interaction and truly collaborative work. Yet, teachers often struggle to adapt their teaching to a higher teacher-student ratio or to fully take advantage of the opportunities provided by co-teaching (Blatchford et al., 2007; Solheim \& Opheim, 2018), instead, often relying on whole class teaching, without profiting from the flexibility of the classroom context (Blatchford et al., 2007). Thus, a higher teacher-student ratio is no guarantee for more interaction and engagement or for student literacy success. 


\section{Early literacy education}

Within a socio-cultural approach to early literacy education, student participation and engagement are seen as important premises for high quality teaching, in any subject. Hall (2012) shows that high quality classrooms are more discursive, conversational and dialogic places to be, and that negotiation, tentativeness and power-sharing are important features. Howe et al. (2019) find that elaboration and querying of previous contributions, along with extensive student participation, are positively associated with curriculum mastery. Classrooms with a high degree of dialogic participation have shown higher reading achievement and deeper understanding in students (Applebee et al., 2003; Muhonen et al., 2018), higher student engagement and improved citizenship skills (Wegerif, 2016), as well as increased student reasoning and elaboration (Boyd \& Kong, 2017; Wegerif et al., 1999; Wilkinson et al., 2015).

Shifting now to the literacy discipline, as literacy can be defined as a "collection of cultural and communicative practices shared among members of particular groups", 2 it is particularly relevant that literacy instruction should emphasize participation and effective communication. Accordingly, literacy teachers should organize discussions on texts (Murphy et al., 2009) and incite high student participation (Hall, 2012). Likewise, activities, where the teacher is able to achieve a strong commitment amongst the students, are shown to be advantageous for younger students' literacy learning (Goigoux et al., 2016).

Meaning is a driving force in literacy growth (Hall, 2012) and therefore also in effective literacy education, particularly during the early years. This implies the integration and balancing of learning the codes of written language along with the uses and purposes of literacy which are more meaningful to the learner (Hall, 2012; Parr \& Limbrick, 2010). Furthermore, teachers must provide extensive opportunities for younger students to read and respond to children's literature and to write for a variety of authentic purposes (Hall, 2012). Exemplary teachers offer a broad spectrum of interesting and engaging texts (Williams et al., 2009), often emphasize themes taught through cross-curricular connections (Morrow et al., 1999), and give the young students a variety of literacy experiences, from partner reading, shared reading and guided reading to independent reading; from students' own book choice to explicit instruction; and from daily writing in journals to workshop settings and mini-lessons - all based on students' needs (Hall, 2012). Also, as Knapp (1995, p. 74) underlines, it is a characteristic of excellent teachers that skills are taught as tools to be used immediately (or very soon) in the work of making sense of the printed page, not be mastered for their own sake without application. However, in the age of scientifically based reading curriculum, the focus on meaning can unfortunately be eclipsed by pressure that teachers perceive for young children to master conventional reading skills, particularly those that will be assessed on formal tests (Spencer, 2011).

\footnotetext{
${ }^{2}$ http://www.ncte.org/digital-literacy
} 


\section{A. K. H.Wagner, A. Skaftun \& E. McTigue}

Therefore, at this time of much curricular change and increased assessments, the processes occurring in the classroom are critical to study.

Further, teacher responsiveness and proximity are also core components of high quality and effective literacy education (Goigoux et al., 2016). Effective teachers organize the classrooms in flexible ways that invite both whole-group, small-group, paired, and one-to-one teaching (Hall, 2012). Especially lower-achieving students profit from time spent with the teacher (this has an effect on decoding, reading, linguistic skills and comprehension; Goigoux et al., 2016). Unfortunately, when students spend much time alone, on individual reading or exercises, without the teacher closely following, differences between high and low performing students increase (Goigoux et al., 2016). Effective teachers therefore spend more time in small-group teaching, which may include teacher-directed text activity, literature circles, and explicit teaching in phonics, comprehension and vocabulary (Goigoux et al., 2016). High quality teachers also offer differentiated instruction (Hall, 2012), observe and evaluate their students' literacy development regularly (Duke \& Del Nero, 2011), have a thorough knowledge of each student's level, and are poised to seize the "teachable moment" (Hall, 2012).

However, continually enacting participating, responsive and engaging instructional practices is challenging for teachers, thus smaller class sizes, or higher teacherstudent ratio have been offered as a scaffold to support teachers in this quest.

\section{Theoretical framework: A social conception of literacy practices}

As defined earlier, the Seaside case is rooted in the socio-cultural theory of language, learning and literacy. Along with the Russian psychologist Lev Vygotsky (1978, 1986), we consider language to be a system of tools for higher order thinking (mediated thinking), which develops in the individual child as a process of internalization based on participation in meaningful social action (social mediation). Vygotsky has been and is an inspiration for different fields of research, very often in conjunction with another Russian scholar, the literary scholar and language philosopher Mikhail Bakhtin, known for his influential work on interaction and dialogic relationships between voices and minds. Vygotsky and Bakhtin complement each other (cf. Holquist, 2003; Wertsch, 1991), and together they form the basis for both a social approach to literacy often referred to as New Literacy Studies (Gee, 2000) and a broad branch of educational research which we will refer to as dialogic education or dialogic teaching. Wegerif (2016) suggests the term dialogic literacy as a way of linking literacy education and classroom talk as resources for the development and teaching of thinking in school. This link between literacy, talk and thinking in educational practice is a key frame of reference in the Seaside case study.

As literacy is a many-faceted phenomenon, it can be studied from different vantage points. The Seaside case considers literacy as a social phenomenon in the tradition of New Literacy Studies (Gee, 2000). New Literacy Studies has typically employed an ethnographic approach to situations where people are engaged in activities that involve 
the use of texts. From the outset the pioneers turned towards out-of-school contexts, describing literacy events (Heath, 1983) and literacy practices (Street, 1984) conceived of as social structures to be analysed based on observation and interviews with the participants. The understanding of these events and practices has subsequently turned into key concepts in the New Literacy Studies' approach to literacy. Ironically, even though this approach started out with an ambition of releasing the understanding of literacy from association with the dominant view of literacy as something taught in school, it has eventually also turned out to be highly productive perspectives on what goes on in school (Ivanič, 2009), often in combination with a focus on classroom discourse (cf. Bloome et al., 2004).

Inspired by New Literacy Studies, we consider literacy as a matter of access on different levels (written signs, text meaning and cultural perspectives, cf. Skaftun, 2015) and, correspondingly, that the teaching of literacy has different purposes as it progresses from basic literacy, through intermediate literacy to disciplinary literacy (Shanahan \& Shanahan, 2008). In school, this progression is to a high degree associated with talk about texts (Skaftun, 2020). Literacy events in school are determined by underlying practices, and they continuously contribute to changing or sustaining such practices.

Practice is a fundamental concept in sociocultural approaches to literacy (cf. Barton, 1994; Gee, 1996, 2009) and discourse (Bloome et al., 2004; Gee, 2014; van Leeuwen, 2008). The social structure of a practice consists of a set of key elements-participants, actions, setting (time and space), and artefacts - and can also be further broken down into aspects of these elements, as in van Leeuwen's approach to discourse and practice (van Leeuwen, 2008). Of particular importance to the Seaside case is what van Leeuwen calls eligibility conditions for participation. Traditional practice provides teachers and students with tightly scripted conditions which are evidently visible in classroom interaction. The dominant talk genres (Bakhtin, 1986; Mortimer \& Scott, 2003) are often based on the previously mentioned IRE pattern of classroom discourse, where the teacher has the initiative and evaluates student response. Acquiring the genres of classroom discourse is an important part of the social learning that takes place during the first years of school (Mehan, 1979), and over time these conditions for participation are mastered to perfection by the students. Dialogic teaching focuses on opening dialogue (Nystrand, 1997) or expanding the repertoire of talk for learning and teaching (Alexander, 2008) to include dialogic space (Wegerif, 2013) and the opportunity for students to make use of their own voices and to be heard (Segal \& Lefstein, 2016).

Curricular reforms in our millennium (Ministry of Education and Research, 2006; The Norwegian Directorate for Education and Training, 20203) increasingly emphasize student participation and active learning, and also the professional community of teachers working together to develop and renew practices in their schools and classrooms. The teacher norm (2018) is an important part of this picture, as a means for supporting teachers in making space for productive approaches to learning in early

\footnotetext{
${ }^{3}$ https://www.udir.no/laring-og-trivsel/lareplanverket/fagfornyelsen/nye-lareplaner/
} 


\section{A. K. H.Wagner, A. Skaftun E E. McTigue}

years education. When an extra teacher is added in the classroom, the social order of the practice can be altered quite substantially. The extent and the direction of the change depends on a set of conflicting forces that might be simplified as a struggle between the pullback effect of traditional practice and the push forward effect of innovation. Traditional practice (Goodlad, 2004; Hicks, 1996) is typically associated with teacher control and discipline as conditions for learning, whereas progressive approaches aim for students working actively on their understanding (Barnes, 1990). This struggle is not a new one. A long tradition of progressive pedagogy (Biesta, 2013; Dewey, 2018; Freire \& Macedo, 1987; Mercer et al., 2019) has been working towards changing the structures of participation in the classroom. This task has proven to be a difficult one (Barnes, 2008; Lefstein, 2008; Møller et al., 2009). Both teachers and students are deeply rooted in underlying understandings of knowledge, learning and teaching (Argyris \& Schön, 1978; Barnes \& Shemilt, 1974; Wilkinson et al., 2017), which will determine how the added teacher resource affects the classroom practice. The Seaside case will provide real life images of the tension between overall governmental intentions and educational practices.

\section{Methods}

\section{Participants and sampling}

The participants in the Seaside case are six classes and their teachers from six different schools in the Seaside municipality. All schools participate in the Two Teachers in the Class RCT (see Appendix 1), and the classes volunteering to be part of the Seaside case are all intervention classes, meaning that they had one extra teacher in all 8 L1 Norwegian lessons each week, in Year One and Year Two.

In Norwegian Years One to Four the class teacher (T1) teaches most lessons. This is the case also for our Seaside classes. Also, in all classes, the additional teacher (T2) is involved either in another subject or as a special needs teacher, and thus a familiar adult. Table 1 shows an overview of the six classes regarding class

Table 1. Overview of the 6 Seaside classes (based on information from Year Two)

\begin{tabular}{lccccccc}
\hline & \multicolumn{2}{c}{ Number of students } & \multicolumn{2}{c}{ Education } & \multicolumn{2}{c}{ Experience } \\
\cline { 2 - 8 } & In the Seaside class & In School & In Grade & T1 & T2 & T1 & T2 \\
\hline C1 & 18 & 230 & 44 & BEd & BEd & 29 & 27 \\
C2 & 20 & 310 & 44 & BEd & $\star)$ & 16 & 27 \\
C3 & 14 & 233 & 33 & BEd & BEd & 23 & 16 \\
C4 & 18 & 319 & 51 & BEd & BEd & 20 & 11 \\
C5 & 16 & 534 & 80 & BEd & $\star \star)$ & 2 & $\star \star)$ \\
C6 & 19 & 308 & 37 & BEd & BEd & 12 & 19 \\
\hline
\end{tabular}

$\mathrm{BEd}=$ Bachelor of Education (3-4 years of teacher education)

*) University or college education of 3 years or less

$\star \star)$ The T2 resource was not given to one specific teacher but alternated between different teachers. 
size and number of students in grade and school, as well as the teachers' education and experience.

\section{Making the case}

The case is well suited for studies of rich phenomena and thus appropriate for the kind of holistic approach we sought. While the main strength of the RCT is breadth, the case gives depth; detail, richness, and within-case variance (Flyvbjerg, 2011), and offers vital evidence to complement more experimentally organized effect studies. Case studies are also relevant when it comes to seeking to explain the 'hows' and 'whys' that require extensive and in-depth description of social phenomena (Yin, 2014), as well as good opportunities to learn (Stake, 2013). As noted previously, this is highly relevant both when it comes to providing contextual background for a deeper understanding of the results of the Two Teachers in the Class RCT, and also when it comes to giving a deeper insight into literacy practices taking place in the everyday life of classrooms, classroom processes, roles and teacher cooperation that occur under different conditions. Finally, the implementation of the Teacher Norm (autumn 2018), with a higher teacher-student ratio and more teachers in the class as the new everyday life of Norwegian elementary school classrooms, adds relevance to the Seaside case. As a result, our sample of classrooms with two teachers in L1 lessons became far more representative of Norwegian classrooms in general.

The municipality is a meaningful organizational context binding the separate schools and classrooms into an embedded case. In Norway, it is at the level of the municipality (school owner) that decisions are made, such as for example participation in various school-based competence programs or decisions concerning students' learning resources.

Seaside is a medium size rural municipality in strong growth (www.ssb.no), including a total of nine primary schools. Sixteen per cent of the population are immigrants (compared to fourteen per cent on the national level; annual report from Seaside, 2018, www.ssb.no), with Eastern European immigrants being the largest group. The population of the municipality has education levels consistent with average educational attainment in Norway. Seaside is a relatively wealthy municipality, which is reflected in the school environment. In total, this demographic information suggests that our case is well suited to display variations found within relatively privileged Norwegian schools.

\section{Data collection and sources}

The Seaside case stretches over two years (Year One and Year Two). Classroom observations constitute the most important data source for the Seaside case. We also interview teachers and school leaders. 


\section{A. K. H.Wagner, A. Skaftun E E. McTigue}

\section{Observational data}

During Year One (2016/2017), the team of researchers spent time observing a total of 26 lessons in Seaside's six intervention classrooms (see Table 2, below). Year One constituted an exploratory stage of the Seaside case, with aims to generate hypotheses, understand life in classrooms with two teachers, and develop tools for the case study. The observations were performed towards the end of the autumn and spring term, and the data produced consisted of field notes, as well as narrative summaries calling attention to aspects of organization, language exposure and more generally 'pedagogical opportunity spaces'. The field notes were written in a table format (see Appendix 3). This was based on an ambition to grasp the workflow intuitively by moving to a new row for each activity shift (or new literacy event) and also indicating the time. Naturally occurring conversations with teachers and students are also referred to in the field notes.

During Year Two (2017-2018), in order to better capture life in the classrooms, the team of researchers spent time observing one full week in each of the six intervention classes. The week is an important unity, especially since the main teacher teaches almost all subjects in Norwegian primary school. What happens in the L1 classroom is therefore connected to other subjects and different events during the day and the week.

Table 2. Number of lessons observed

\begin{tabular}{|c|c|c|c|c|c|c|c|c|c|}
\hline & & & C1 & C2 & C3 & C4 & C5 & C6 & Total \\
\hline $\begin{array}{l}\text { Year One } \\
(2016-17)\end{array}$ & $\begin{array}{l}\text { Number of } \\
\text { lessons observed }\end{array}$ & Norwegian & 4 & 5 & 6 & 5 & 1 & 5 & 26 \\
\hline \multirow{11}{*}{$\begin{array}{l}\text { Year Two } \\
(2017-18)\end{array}$} & \multirow{10}{*}{$\begin{array}{l}\text { Number of } \\
\text { lessons observed }\end{array}$} & Mathematics & 5 & 5 & 6 & 5 & 5 & 3 & 29 \\
\hline & & Science & 1 & 1 & 0 & 0 & 2 & 0 & 4 \\
\hline & & English & 0 & 1 & 1 & 1 & 1 & 1 & 5 \\
\hline & & L1 Norwegian ${ }^{\star}$ ) & & & 1 & 2 & & & 3 \\
\hline & & Religion/ethics & 2 & 1 & 2 & 0 & 1 & 1 & 7 \\
\hline & & "Research-hour" & 0 & 0 & 0 & 0 & 0 & 3 & 3 \\
\hline & & Art and Crafts & 0 & 0 & 0 & 0 & 2 & 0 & 2 \\
\hline & & Social studies & 0 & 0 & 0 & 3 & 0 & 0 & 3 \\
\hline & & Class meeting & & & & & & 1 & 1 \\
\hline & & Music & 0 & 0 & 0 & 0 & 0 & 1 & 1 \\
\hline & $\begin{array}{l}\text { Number of } \\
\text { lessons observed } \\
\text { and filmed }\end{array}$ & L1 Norwegian & 8 & 8 & 8 & 8 & 7 & 8 & 47 \\
\hline Total Year Two & & & 16 & 16 & 18 & 19 & 18 & 18 & 105 \\
\hline TOTAL & & & 20 & 21 & 24 & 24 & 19 & 23 & 131 \\
\hline
\end{tabular}

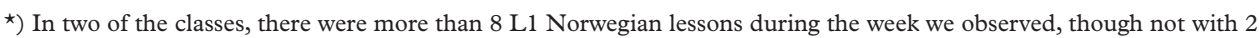
teachers present. These were observed, but not filmed.

We did not observe gymnastics, excursions and outdoor school, nor, generally, art and crafts and music. 
Field notes (see example in Appendix 3) were made from all the different subjects (see Table 2, above). As for Year One, the field notes were written in a table format. In addition to running notes, we registered, in the left margin and for each activity, whether the two teachers were both in the same room, or whether they divided the class between them (relevant for L1 lessons, but sometimes also for other lessons); organization of classroom activities (individual, pair, group, plenary, station); and what type of activity (reading, writing, guided reading, guided writing, student talk).

Narrative summaries (see example in Appendix 4) were written for each day. In addition to grasping the school day and its lessons as a whole, these focused on teacher co-operation (such as hierarchy, integration, sharing of workload, signs of common cooperation); oracy (both students and teachers: such as response, follow-ups, challenges, types of questions); reading activities taking place (such as teacher's reading for the class, students' own reading, going through reading lesson etc); writing activities taking place (such as fill-in tasks; letter formation practice, individual text writing), and digital technology being used (type of technology, use of technology, organization, practical challenges).

Filmed observations of all L1-lessons in each of the six classes (a total of 47 lessons, à 45 minutes) were also carried out (see Table 2). Due to the holistic focus of the Seaside case, our filming approach has been the same, with filming of whole lessons and both classrooms and group rooms-as opposed to more focused filming of extracts/segments of lessons, based on more targeted research questions. We have recorded sound from two cameras and from each of the teachers. One wide-angle camera (ZoomQ8) was placed in the back corner of the main classroom, and captured the whole class. An additional camera (ZoomQ4) was placed in group rooms/ where the teacher took groups of students. Both teachers wore wireless microphones (Sennheiser AVX-ME2, consisting of lapel mike ME2, pocket transmitter SK AVX and receiver EKP AVX). Together, the equipment captured both classroom and group room sound, as well as teacher-students' interactions and conversations.

\section{Interview data}

During Year One we conducted semi-structured interviews:

- with the six teacher pairs. The themes of the interviews were cooperation in planning, teaching, evaluation; adapted education with two teachers; the teachers' experiences with being two teachers in the L1 literacy education; obstacles; and the teachers' possible use of the Internet-based program for professional development in literacy instruction ('Language Tracks').

- with the six headmasters. The themes of the interviews were the headmaster's role in making the most out of two teachers/positive effect; possible obstacles in school or for the two teachers; possible changes in school culture due to the Two Teachers project; any guidance on the teachers' unrestrained time; and possible organizational problems involved with assigning two teachers to a class. 


\section{A. K. H.Wagner, A. Skaftun \& E. McTigue}

(It is important to note that the Year One interviews were based on preliminary hypotheses, and do not cover all aspects of interest of the case study as it subsequently developed.)

During the extensive observations in Year Two, field conversations with the teachers involved occurred over the course of the day and the week. Typically, these transpired when students were working individually, between lessons on the way to and from the classroom, and in the lunch breaks at the staff room. These conversations were not systematically audio recorded beyond that some of them took place while the teacher was carrying the microphone (audio recording device), but they are referred and reflected on in field notes and narrative summaries.

Finally, in autumn in Year Five we will invite all teachers and their school leaders to a seminar. At this point, we will present some of the findings from the Seaside case, share and validate our findings and get the teachers' and school leaders' reflections and comments on perspectives on classroom practice and retrospective reflections on the effects of increased teacher density.

\section{Researcher positions}

In both Year One and Year Two, the researchers divided the schools between them, in order to create confidence and to get acquainted with the teachers and their ways of working. When it was natural, we responded to situations that arose (conversations with teachers or interactions with students), otherwise and most of the time, we remained calm, in the back of the classroom. Our participation thus varied a little from classroom to classroom.

The interviews during Year One were conducted after the observation period, and by the researcher that had spent time in the class and who knew the teachers. The interviews with the school leaders were all conducted by the same researcher, after the observation period.

\section{Methods for analyses}

Analytical procedures are conducted within a shared project file in NVivo for Teams, containing both fieldnotes, narrative summaries, video recordings from classrooms and group rooms, as well as transcriptions of all recordings. The data is coded in order to reduce the complexity of 131 hours of classroom activity, moving from overarching, descriptive coding towards an interpretive stance that allows us to develop and apply more interpretive codes to limited parts of the material. To date, we coded whole sequences associated with a set of specific literacy events (Table 3, type of code 1). All observational data types are coded for organizational forms (Table 3, type of code 3) and teacher collaboration (Table 3, type of code 2). In transcriptions, all utterances were ascribed to speakers), allowing a detailed overview of the distribution of utterances and speech time (Table 3, type of code 4) during classroom activities in the L1 literacy lesson. 
Table 3. Overview of preliminary codes

\begin{tabular}{lll}
\hline Type of code & Codes & Based on \\
\hline 1. Literacy events & Guided reading & Derived from both \\
& Homework & Conversations about text \\
& Circle time & from research \\
& Distribution of questions & \\
& T1 in the classroom; T2 in the classroom; T1 and T2 in & Friend et al., 2010; \\
the classroom together; distribution of different forms of & Friend, 2016 \\
of collaboration & collaboration (One leads-one observes, parallel teaching, & \\
& teaming, alternative teaching, etc.) & \\
\hline 3. Organizational form & Whole class teaching, individual seat work, station work, & Alexander, 2008; \\
& work in groups and pairs. & Hodgson et al., \\
& & 2012; Klette, 2003 \\
\hline 4. Distribution of talk & Generalized speaker identified: T1, T2, G(irl) B(oy), & \\
& R(esearcher), sometimes an extra assistant & \\
\hline 5. Types of talk & Narrative sharing (student dominance) & Conversation (teacher and students) \\
& Recitation (instruction involving students) & Formalised talk (including reading aloud, singing, etc.) \\
& Dialogue between teachers & 2001, 2008
\end{tabular}

Whole class teaching is further coded for types of talk (Table 3, type of code 5) based on the work of Alexander $(2001,2008)$. In Alexander's (2001) comparative studies of classroom interaction, he found a basic repertoire of three types of teaching talk (rote, recitation, instruction). Less frequent, but still universally, he found that teachers make use of discussion and dialogue (Alexander, 2008). We have added to and reorganized this typology in order to resonate with our empirical basis and also our key interest in eligibility conditions for participation (Skaftun \& Wagner, 2019). Our modified list of categories is organized as a continuum from teacher domination on the one hand side (teacher instruction) to potential student domination on the other (narrative sharing is added to the list) with recitation as intermediary. We have also added dialogue between teachers as a category. Rote does not apply to the classroom practices observed, but reading aloud and singing are particular ways of using voice and mind that we have tagged as formalised talk. Finally, Alexander's two categories, discussion and dialogue, are merged into one category for dialogic potential, tagged conversation. The coding procedure implies closing in on this dialogic potential.

All coding is done by researchers working in pairs in order to support reliability, and uncertainties are solved through inter-rater negotiations. The primary purpose of the coding procedure is to make the database searchable by categories and by cross-referencing the categories, allowing us to narrow the scope to specific phenomena, which will be subjected to in-depth qualitative analysis and interpretations 


\section{A. K. H.Wagner, A. Skaftun E E. McTigue}

in separate articles (see below). Making the events visible and providing contextual evidence from the data will be our primary way of ensuring valid and reliable interpretations of what goes on in specific events and in specific classrooms. All analysis will be performed with reference to and in fidelity to the framework provided in this protocol.

\section{Dissemination}

The research questions will be elucidated in various scientific articles covering the following themes:

- The use of guided reading (RQ 1): Guided reading is a widely used approach to early reading education that has become a frequent practice in Norwegian classrooms. In this article we will explore how teachers exploit the potential of guided reading practices and how different aspects of literacy instruction are integrated.

- The practice and pedagogical use of homework (RQ 1): Homework - and reading lessons in particular - constitute an important part of the L1 literacy practice. In this article we will explore the practice of homework with a particular focus on how it is used as a pedagogical tool in L1 literacy education.

- Circle time as an opportunity space for dialogic literacy (RQ 1, 3): Circle time, as a variant of whole class teaching, represents a more intimate space for interaction and as such a potentially productive dialogic space. In this article we will explore which literacy practices occur in circle time with a particular interest in narrative sharing.

- Whole class conversation about texts (RQ 1): Discussing texts is an essential part of L1 literacy. In this article whole class discussion about texts with conversational qualities will be analysed, with a particular focus on the pedagogical purpose and underlying conceptions of text.

- Teacher collaboration in co-taught classrooms (RQ 2): Two teachers in class represents new opportunities as well as some challenges concerning ways to share professional responsibility and professional roles. In this article we will analyse teacher collaboration as it transpires in time and space as a basis for discussing how the additional teacher resource affects practice.

- Dialogic space in whole class interaction (RQ 3): Whole class teaching takes up a considerable amount of classroom time, and it provides the most direct insight into the eligibility conditions for student participation. A study based on more limited data from Year One serves as a pilot for a more in-depth study of all the Year Two data by focusing on the conditions for student voices.

- Questions in whole class interaction (RQ 3, 1): Questions are a well-known feature of whole class teaching and associated with instructional quality. In this article we will investigate the distribution and qualitative aspects of questions during whole class teaching, with a particular interest in student initiatives and sequences that display conversational qualities. 
The research questions will also be answered more holistically in an Open Access book presented as a case report, where the three overarching research questions provide the structure for the book framed by an introductory chapter with an overall reflection of results and experiences.

\section{Ethical considerations}

Written and informed participation consents from teachers and the parents of the students have been obtained as part of the Two Teachers RCT, in accordance with the ethics guidelines of the Norwegian Centre for Research Data (NSD), a thirdparty ethical oversight agency in Norway. In addition, the teachers participating in the Seaside case have approved the (filmed) observations of their class. The teachers were informed that the researchers wished to observe aspects of teacher cooperation and literacy practices. In a few cases, where students did not have written consent from parents for participation in the RCT, we collected consents for participation in the classroom observations of the Seaside case, also in accordance with NSD. The project follows the Ethical guidelines of NSD, as well as the guidelines developed by the National Committee for Research Ethics in the Social Sciences and Humanities (NESH). All data are stored securely and only accessible by the research group and authorized personnel. Access for site investigators requires a formal request (describing plans) approved by the chief investigators. Filmed observations will be deleted in 2023. The researchers will ensure that the participants' anonymity is maintained. All classes will be referred to by class/school number only, and teachers' and students' names will be anonymized.

\section{Limitations}

There are limitations to our case study, concerning both quality and amount of data. First, we do not have any systematic information on how the teachers experienced having researchers observing and filming their lessons for a whole week, and how this might have impacted the teaching. The Hawthorne effect, in other words, the tendency for people to change their behaviour simply as a result of being observed, is well documented by social scientists (Salkind, 2010). The embedded nature of our work (the same researcher remained within the same class) can attenuate, but not completely erase this phenomenon. Second, even if we had teachers' selfreports on how they planned the lessons together (see Appendix 1), we do not have any qualitative information on this, only on how the collaboration took place in the classrooms. The intention and the operationalization of their co-teaching may not have been fully consistent. Also, qualitative interviews with teachers and school leaders (on experiences of being two teachers, adapted education, obstacles and challenges at the school level etc.) took place only in Year One. Again, we do however have their yearly self-reports, which provide similar information, but with 


\section{A. K. H.Wagner, A. Skaftun \& E. McTigue}

less depth. Moreover, planned class observations and conversations with teachers in Year Four had to be abandoned due to the Covid-19-situation. Third, even with cameras in both the main classrooms and group rooms and microphones on both teachers, these audio-visual resources in the main classroom did not capture everything. For example, it is difficult from video sources to identify what textbooks the students read or what they wrote. We typically recorded this information in field notes, but such details are not always mentioned. Furthermore, at select times, when one of the teachers stood by the wall at the back of the main classroom (often observing the other teacher), she can be hard to see. However, these were often situations in which there was limited interaction with students. Additionally, in the main classroom, when the teacher talked to individual students during seat work, it can sometimes be hard to capture what other students are saying. In contrast, in group rooms, the microphones on the teacher and in the camera capture well what both teacher and students say.

There are limitations also to our ethnographic approach trusting fieldnotes and narratives written by different researchers. This uncertainty is balanced by access to video files from the L1 lessons, and active checking across the different data types. The initial analytical procedures are mainly based on descriptive codes, but borderline cases calling for interpretation are an unavoidable part of the game, adding an element of uncertainty to the aggregated results based on the coding. Most vulnerable is the coding of types of talk in whole class teaching, and particularly the category conversation, containing dialogic potential beyond the brief exchanges characteristic of recitation. The uncertainty is countered by coding communities (researcher pairs) reaching agreement through discussion. Our primary concern in coding types of talk has been not to overlook dialogic qualities in the data reduction. These dialogic qualities are essential to our interest in student participation in the overall Seaside case, and they are subjected to close reading in different sub-studies.

\section{Acknowledgements}

The authors are grateful to the students, teachers and headmasters who participated in our case study for inviting us into their classrooms and schools. We also thank Professor Oddny J. Solheim and Professor Per Henning Uppstad for valuable comments on earlier versions of the manuscript. We are also grateful for support and goodwill from the Reading Centre.

\section{Research group}

Chief Investigators

Professor Åse Kari H. Wagner, University of Stavanger

Professor Atle Skaftun, University of Stavanger 


\section{Co-Investigators}

Associate Professor Arild M. Bakken, University of Stavanger

Lecturer Ingeborg M. Berge, University of Stavanger

Senior Lecturer Toril F. Hoem, University of Stavanger

Associate Professor Anne Håland, University of Stavanger

Associate Professor Erin McTigue, University of Stavanger

Senior Lecturer Margunn Mossige, University of Stavanger

Associate Professor Arne Olav Nygard, University of Stavanger

Associate Professor Margrethe Sønneland, University of Stavanger

Lecturer Marit Aasen, University of Stavanger

\section{Funder}

The Seaside case is part of the Two Teachers in the Class RCT, which is funded by The Research Council of Norway, Research Programme "LÆREEFFEKT", grant number: 256197.

\section{Author biographies}

Åse Kari H. Wagner, $\mathrm{PhD}$, is a professor in Scandinavian languages at National Centre for Reading Education and Research, University of Stavanger. Her current research interests are language development, dialogic education, language and reading, and assessment.

Atle Skaftun, $\mathrm{PhD}$, is a professor in literacy studies at National Centre for Reading Education and Research, University of Stavanger. His current research interests are literacy and literature education, and digital and oral conditions for dialogic participation and thinking in Norwegian classrooms.

Erin M. McTigue, PhD, is Research Scientist \& Associate Professor II at the National Center for Reading Education and Research, University of Stavanger, Norway. Her current research interests are literacy in early childhood education and students' motivation in literacy.

\section{References}

Alexander, R. J. (1997). Policy and practice in primary education: Locale initiative, national agenda. Routledge. Alexander, R. J. (2001). Culture and pedagogy: International comparisons in primary education. Blackwell Oxford. Alexander, R. J. (2008). Towards dialogic teaching: Rethinking classroom talk (4th ed.). Dialogos.

Applebee, A. N., Langer, J. A., Nystrand, M., \& Gamoran, A. (2003). Discussion-based approaches to developing understanding: Classroom instruction and student performance in middle and high school English. American Educational Research fournal, 40, 685-730. https://doi.org/10.3102/00028312040003685

Argyris, C., \& Schön, D. A. (1978). Organizational learning: A theory of action perspective. Addison-Wesley. Bakhtin, M. (1986). Speech genres and other late essays (M. Holquist \& C. Emerson, Eds., V. W. McGee, Trans.). University of Texas Press. 


\section{A. K. H.Wagner, A. Skaftun E E. McTigue}

Barnes, D., \& Shemilt, D. (1974). Transmission and interpretation. Educational Review, 26(3), 213-228. https:// doi.org/10.1080/0013191740260305

Barnes, D. (1990). Language in the secondary classroom. In D. Barnes, J. Britton, \& M. Torbe (Eds.), Language, the learner and the school (4 ${ }^{\text {th }}$ ed.). Boynton/Cook publishers.

Barnes, D. (2008). Exploratory talk for learning. In N. Mercer \& S. Hodgkinson (Eds.), Exploring talk in school. Sage.

Barton, D. (1994). Literacy: An introduction to the ecology of written language. Blackwell.

Biesta, G. J. J. (2013). The beautiful risk of education. Routledge.

Blatchford, P., Russell, A., Bassett, P., Brown, P., \& Martin, C. (2007). The effect of class size on the teaching of pupils aged 7-11 years. School Effectiveness and Improvement, 18, 2, June, 147-172. https://doi.org/ 10.1080/09243450601058675

Bloome, D., Carter, S. P., Christian, B. M., Otto, S., \& Shuart-Faris, N. (2004). Discourse analysis and the study of classroom language and literacy events: A microethnographic perspective. Routledge.

Boyd, M., \& Kong, Y. (2017). Reasoning words as linguistic features of exploratory talk: Classroom use and what it can tell us. Discourse Processes, 54(1), 62-81. https://doi.org/10.1080/0163853X.2015.1095596

Bressoux, P. (2016). Research on class size in France. Class Size (pp. 100-111). Routledge.

Brown, N. B., Howerter, C. S., \& Morgan, J. J. (2013). Tools and strategies for making co-teaching work. Intervention in School and Clinic, 49(2), 84-91. https://doi.org/10.1177/1053451213493174

Carty, A., \& Marie Farrell, A. (2018). Co-teaching in a mainstream post-primary mathematics classroom: An evaluation of models of co-teaching from the perspective of the teachers. Support for Learning, 33(2), 101-121. https://doi.org/10.1111/1467-9604.12198

Cazden, C. B. (2001). Classroom discourse: the language of teaching and learning (2nd ed.). Heinemann.

Dewey, J. (2018). Democracy and education: An introduction to the philosophy of education. Createrspace Independent Publishing.

Duke, N. K., \& Del Nero, J. R. (2011). Best practices in literacy instruction. Guilford Press.

Flyvbjerg, B. (2011). Case Study. The SAGE Handbook of Qualitative Research (4th ed., pp. 301-316).

Freire, P., \& Macedo, D. (1987). Literacy: Reading the word E the world. Routledge.

Friend, M., \& Barron, T. (2016). Co-teaching as a special education service: Is classroom collaboration a sustainable practice? Educational Practice and Reform, 2. https://journals.radford.edu/index.php/EPR/ article/view/55

Friend, M., Cook, L., Hurley-Chamberlain, D., \& Schamberger, C. (2010). Co-teaching: An illustration of the complexity of collaboration in special education. Fournal of Educational and Psychological Consultation, 20(1), 9-29. https://doi.org/10.1080/10474410903535380.

Gee, J. P. (1996). Social linguistics and literacies: Ideology in discourses. Routledge.

Gee, J. P. (2000). The new literacy studies. From socially situated to the work of the social. In D. Barton, M. Hamilton, Ivanič, R., \& R. Ivanič (Eds.), Situated literacies: Reading and writing in context. Psychology Press.

Gee, J. P. (2009). New digital media and learning as an emerging area and "worked examples" as one way forward. MIT Press.

Gee, J. P. (2014). An introduction to discourse analysis: Theory and method. Routledge.

Gilje, Ø., Bjerke, Å., Thuen, F., \& Bolstad, B. (2020). Gode eksempler på praksis. En-til-en-dekning $i$ klasserommet [Good examples of practice. One-to-one coverage in the classroom]. University of Oslo.

Goigoux, R. et al. (2016). Lire et écrire. Étude de l'influence des pratiques d'enseignement de la lecture et de l'écriture sur la qualité des premières apprentissages ['Beginning reading and writing. Study on the influence of teaching practices on quality of basic learning']. Université de Lyon/Institut français de l'éducation. Report, 446 pages. http://www.reseau-espe.fr/recherche/publications/lire-et-ecrire-etude-de-l-influence-des-pratiquesd-enseignement-de-la

Goodlad, J. (2004). A place called school: Twentieth anniversary edition (2nd ed.). McGraw-Hill Education.

Hall, K. (2012). Effective literacy teaching in the early years of school: A review of evidence. In J. Larson \& J. Marsh (Eds.), The SAGE Handbook of Early Childhood Literacy (2nd ed., pp. 523-540). Sage. https://doi. org/10.4135/9781446247518.n29

Heath, S. B. (1983). Ways with words: Language, life and work in communities and classrooms. Cambridge University Press.

Hicks, D. (1995). Discourse, learning, and teaching. Review of Research in Education, 21(1), 49-95. https://doi. org/10.3102/0091732X021001049

Hodgson, J., Rønning, W., \& Tomlinson, P. (2012). Sammenhengen mellom undervisning og lering. En studie av lereres praksis og deres tenkning under Kunnskapsløftet ['The relationship between teaching and learning: 


\section{Literacy practices in co-taught early years classrooms}

A study of teachers' practices and their thinking during the "Knowledge Boost" curriculum reform']. Sluttrapport [final report] (NF-report 4/2012). Nordlandsforskning.

Holquist, M. (2003). Dialogism: Bakhtin and his world. Routledge. https://doi.org/10.4324/9780203425855

Howe, C., Hennessy, S., Mercer, N., Vrikki, M., \& Wheatley, L. (2019). Teacher-student dialogue during classroom teaching: Does it really impact on student outcomes? Fournal of the Learning Sciences, 28(4-5), 462-512. https://doi.org/10.1080/10508406.2019.1573730

Hughes, C. E., \& Murawski, W. A. 2001. Lessons from another field: Applying co-teaching strategies to gifted education. Gifted Child Quarterly, 45, 195-204. https://doi.org/10.1177/001698620104500304

Ivanič, R. (2009). Bringing literacy studies into research on learning across the curriculum. In M. Baynham \& M. Prinsloo (Eds.), The future of literacy studies (pp. 100-122). Palgrave Macmillan. https://doi. org/10.1057/9780230245693_6

Klette, K. (Ed.). (2003). Klasserommets praksisformer etter Reform 97 ['Classroom practices after "Reform 97" ']. https://www.duo.uio.no/bitstream/handle/10852/32308/Reform97_Rapp_1_03_web.pdf?sequence=18is Allowed $=\mathrm{y}$

Knapp, M. S. (1995). Teaching for meaning in high-poverty classrooms. Teachers College Press, Columbia University.

Lefstein, A. (2008). Changing classroom practice through the English National Literacy Strategy: A microinteractional perspective. American Educational Research fournal, 45(3), 701-737. https://doi.org/ $10.3102 / 0002831208316256$

Ludvigsen, S., Gundersen, E., Kleven, K., Rege, M., Øye, H., Indregard, S., \& Sundberg, D. (2015). Fremtidens skole. Fornyelse av fag og kompetanser, 8 [School of the future. Renewal of subjects and competencies] https:/www.regjeringen.no/contentassets/da148fec8c4a4ab88daa8b677a700292/no/pdfs/ nou201520150008000dddpdfs.pdf

Mackey, J., O'Reilly, N., Jansen, C., \& Fletcher, J. (2018). Leading change to co-teaching in primary schools: a "Down Under" experience. Educational Review, 70(4), 465-485. https://doi.org/10.1080/00131911.20 17.1345859

Mastropieri, M. A., Scruggs, T. E., Graetz, J., Norland, J., Gardizi, W., \& McDuffie, K. (2005). Case studies in co-teaching in the content areas: Successes, failures, and challenges. Intervention in school and clinic, 40, 260-270. https://doi.org/10.1177/10534512050400050201

Maxwell, J. A. (2009). Designing a qualitative study. In L. Bickman \& D. J. Rog (Eds.), The SAGE handbook of applied social research methods (2nd ed., pp. 214-253). SAGE.

Mehan, H. (1979). Learning lessons: Social organization in the classroom. Harvard University Press.

Mercer, N., Wegerif, R., \& Major, L. (Eds.). (2019). The Routledge international handbook of research on dialogic education. Routledge.

Ministry of Education and Research. (2006). Lareplanverket for kunnskapsloftet [The curricularreform The Knowledge Promotion]. https://sokeresultat.udir.no/finn-lareplan.html?ftypefiltermulti=Kunnskapsl\%C3\%B8ftet\%20 2006

Morrow, L. M., Tracey, D. H., Woo, D. G., \& Pressley, M. (1999). Characteristics of exemplary first-grade literacy instruction. The Reading Teacher, 52(5), 462-76. https://www.jstor.org/stable/20202104?seq=1

Mortimer, E., \& Scott, P. (2003). Meaning making in secondary science classrooms. Open University Press.

Muhonen, H., Pakarinen, E., Poikkeus, A.-M., Lerkkanen, M.-K., \& Rasku-Puttonen, H. (2018). Quality of educational dialogue and association with students' academic performance. Learning and Instruction, 55, 67-79. https://doi.org/10.1016/j.learninstruc.2017.09.007

Murawski, W., \& Swanson, H. (2001). A meta-analysis of co-teaching research: Where are the data? Remedial and Special Education, 22, 258-267. https://doi.org/10.1177/074193250102200501

Murphy, P. K., Wilkinson, I. A., Soter, A. O., Hennessey, M. N., \& Alexander, J. F. (2009). Examining the effects of classroom discussion on students' comprehension of text: A meta-analysis. Fournal of Educational Psychology, 101(3), 740. https://doi.org/10.1037/a0015576

Møller, J., Prøitz,T. S., \& Aasen, P. (2009). Kunnskapsløftet - tung bør å bcere? Underveisanalyse av styringsreformen $i$ skjaringspunktet mellom politikk, administrasjon og profesjon [The Knowledge Promotion - a heavy burden to carry? Preliminary analysis of the governance reform at the intersection of politics, administration and profession]. NIFU STEP. https://www.nifu.no/publications/318939/

The Norwegian Directorate for Education and Training. (2017). Rammeplan for barnehagen. Innhold og oppgaver [Framework plan for Norwegian Kindergarten]. https://www.udir.no/rammeplan

The Norwegian Directorate for Education and Training. (2018). Overordnet del av lereplanverket [General part of the curriculum for school]. https://www.udir.no/laring-og-trivsel/lareplanverket/overordnet-del/ 


\section{A. K. H.Wagner, A. Skaftun E E. McTigue}

Nystrand, M. (Ed.). (1997). Opening dialogue: Understanding the dynamics of language and learning in the English classroom. Teachers College Press.

Nystrand, M., \& Gamoran, A. (1991). Student engagement: When recitation becomes conversation. In H. C. Waxman \& H. J. Walberg (Eds.), Effective teaching: Current research (pp. 257-276). McCutchan. https://files. eric.ed.gov/fulltext/ED323581.pdf

Parr, J. \& Limbrick, L. (2010). 'Contextualising practice: Hallmarks of effective teachers of writing'. Teaching and Teacher Education, 26, 583-90. https://doi.org/10.1016/j.tate.2009.09.004

Pellegrino, J.W., \& Hilton, M. L. (Eds.). (2013). Education for life and work: Developing transferable knowledge and skills in the 21st century. Washington: National Academies Press.

Salkind, N. J. (2010). Encyclopedia of research design (Vols. 1-0). SAGE Publications, Inc. https://doi. org/10.4135/9781412961288

Segal, A., \& Lefstein, A. (2016). Exuberant voiceless participation: An unintended consequence of dialogic sensibilities? L1-Educational Studies in Language and Literature, 16, 1-19. https://doi.org/10.17239/ L1ESLL-2016.16.02.06

Shanahan, T., \& Shanahan, C. (2008). Teaching disciplinary literacy to adolescents: Rethinking content-area literacy. Harvard Educational Review, 78(1), 40-59.https://doi.org/10.17763/haer.78.1.v62444321p602101

Skaftun, A. (2015). Leseopplæring og fagenes literacy. Nordic fournal of Literacy Research, 1. https://doi.org/ 10.17585/njlr.v1.170

Skaftun, A. (2020). Rom for muntlighet? Språklig tenking og tekstsamtaler i norskfagets literacy. Nordic fournal of Literacy Research, 6(1), Article 1. https://doi.org/10.23865/njlr.v6.2022

Skaftun, A., \& Wagner, A. K. H. (2019). Oracy in year one: a blind spot in Norwegian language and literacy education? L1 Educational Studies in Language and Literature, 19, 1-20. https://doi.org/10.17239/ L1ESLL-2019.19.01.09

Slotte, A. (2019). Mer flerspråkigt, mer digitalt, mer uppkoplat - Förändrade förutsättningar för undervisning och lärande i dagens nordiska klassrum [More multilingual, more digital, more connected - Changing conditions for teaching and learning in today's Nordic classrooms]. Keynote at the Nordic research conference Skriv! Les! [Write! Read!].

Solheim, O. J., Rege, M., \& McTigue, E. (2017). Study protocol: “Two teachers": A randomized controlled trial investigating individual and complementary effects of teacher-student ratio in literacy instruction and professional development for teachers. International fournal of Educational Research, 86, 122-130. https:// doi.org/10.1016/j.ijer.2017.09.002

Solheim, O. J., \& Opheim, V. (2018). Beyond class size reduction: Towards more flexible ways of implementing a reduced pupil-teacher ratio. International fournal of Educational Research. https://doi.org/10.1016/j. ijer.2018.10.008

Spencer, T. (2011). Learning to read in the wake of reform: Young children's experiences with scientifically based reading curriculum. Penn GSE Perspectives on Urban Education, 8(2), 41-50. https://eric.ed.gov/ ?id=EJ940932

Stake, R. E. (2013). Multiple case study analysis. Guilford Press.

Street, B. (1984). Literacy in theory and practice. Cambridge University Press.

Van Leeuwen, T. (2008). Discourse and practice: New tools for critical discourse analysis. Oxford University Press. https://doi.org/10.1093/acprof:oso/9780195323306.001.0001

Villa, R. A., Thousand, J. S., \& Nevin, A. I. (2013). A guide to co-teaching: New lessons and strategies to facilitate student learning. Corwin Press.

Vygotsky, L. S. (1978). Mind in society: The development of higher psychological processes. Harvard University Press.

Vygotsky, L. S. (1986). Thought and language (A. Kozulin, Ed.). MIT Press.

Walsh, J. M. (2012). Co-teaching as a school system strategy for continuous improvement. Preventing School Failure: Alternative Education for Children and Youth, 56(1), 29-36. https://doi.org/10.1080/1045988X. 2011.555792

Wegerif, R. (2013). Dialogic: Education for the Internet age. Routledge. https://doi.org/10.4324/9780203111222

Wegerif, R. (2016). Applying dialogic theory to illuminate the relationship between literacy education and teaching thinking in the context of the Internet age. L1 Educational Studies in Language and Literature, 16, 1-21. https://doi.org/10.17239/L1ESLL-2016.16.02.07

Wegerif, R., Mercer, N., \& Dawes, L. (1999). From social interaction to individual reasoning: An empirical investigation of a possible socio-cultural model of cognitive development. Learning and Instruction, 9(6), 493-516. https://doi.org/10.1016/S0959-4752(99)00013-4

Wertsch, J. V. (1991). Voices of the mind: a sociocultural approach to mediated action. Harvard University Press. 
Wexler, J., Kearns, D. M., Lemons, C. J. Mitchell, M., Clancy, E., Davidson, K. A., Sinclair, A. C., \& Wei, Y. (2018). Reading comprehension and co-teaching practices in middle school English language arts classrooms. Exceptional Children, 84(4), 384-402. https://doi.org/10.1177/0014402918771543

Wilkinson, I. A., Murphy, P. K., \& Binici, S. (2015). Dialogue-intensive pedagogies for promoting reading comprehension: What we know, what we need to know. Socializing Intelligence through Academic Talk and Dialogue, 37-50. https://doi.org/10.3102/978-0-935302-43-1_3

Wilkinson, I. A., Reznitskaya, A., Bourdage, K., Oyler, J., Glina, M., Drewry, R., Kim, M.-Y., \& Nelson, K. (2017). Toward a more dialogic pedagogy: Changing teachers' beliefs and practices through professional development in language arts classrooms. Language and Education, 31(1), 65-82. https://doi.org/10.1080/ 09500782.2016.1230129

Williams J. P., Stafford, K. B., Lauer, K. D., Hall, K. M. \& Pollini, S. (2009). Embedding reading comprehension training in content-area instruction. Fournal of Educational Psychology, 101(1), 1-20. https://doi. org/10.1037/a0013152

Yin, R. K. (2014). Case study research: Design and methods. Sage. 


\section{A. K. H.Wagner, A. Skaftun \& E. McTigue}

\section{Appendix 1: The Two Teachers in the Class RCT}

Two Teachers in the Class (Author 3 and colleagues, 2017) is a large RCT investigating the individual and complementary effects of higher teacher-student ratio and professional development for teachers in L1 initial literacy education. The project involves 300 classrooms nested within 150 schools and 53 Norwegian municipalities. It investigates (1) students' achievement in initial reading and spelling, (2) students' literacy interest, reader self-concept and achievement strategies, (3) classroom climate and emotional support and (4) teaching practices in L1 initial literacy instruction, aiming at studying relationships between the students' learning outcomes and motivation and increased teacher density, work with professional development for teachers, and training in specific work methods related to the initial reading education.

To investigate under which learning conditions higher teacher density can contribute to increased student learning in L1 initial literacy education, The Two Teachers RCT has created 3 different conditions, and the participating schools are randomly assigned to one of these. In condition 0 , the intervention classes received an extra teacher resource for the 8 Norwegian lessons a week in Year 1 and Year 2, but the teachers were not required to change their instructional approach, meaning that they represent a 'business as usual' situation. In condition 1, the intervention classes received the extra teacher resource for the 8 Norwegian lessons a week in Year 1 and Year 2. Both intervention classes and control classes also adapted to an Internet-based programme for professional development in literacy instruction (Language Tracks, http://sprakloyper.uis.no). Finally, in condition 2, the intervention classes received the extra teacher resource for the 8 Norwegian lessons a week in Year 1 and 2, as well as receiving additional instructions for how to use the extra teacher in the classroom. Both intervention classes and control classes also adapted to the Language Tracks programme.

The intervention period covers Year 1 and Year 2, whereas Year 3 and Year 4 are follow-ups (Solheim \& Opheim, 2017; Author 3 and colleagues, 2017). The basis for the design of the Two Teachers RCT was research-based assumptions that teacher density alone does not necessarily contribute to productive changes, and that the "active ingredient" lies in how the extra teacher resource is actually utilized in the classroom. In other words, the increased teacher density provides an opportunity space for more meaningful participation and engagement but does not ensure for it.

Two Teachers in the Class RCT collects data from students, teachers and headmasters, concerning student achievement, interest/self-concept/strategies, classroom climate and emotional support, as well as teaching practices. Students are assessed from Year 1 until the beginning of Year 5 in various literacy skills, including letter recognition, reading accuracy, sight word efficacy, phonetic decoding efficacy and spelling, word recognition, spelling and reading comprehension. Students also answer questionnaires about literacy interest, motivation and readers' self-concept. Teachers report on students' achievement strategies. Annually, both students and teachers answer 
questionnaires regarding classroom climate. Students additionally answer a short questionnaire on emotional support. Teaching practices are measured by self-report, via a questionnaire on methods, instructional approaches, teacher collaboration and organization of literacy instruction. For a more comprehensive overview of the quantitative data, see Author 3 and colleagues (2017).

\section{Appendix 2: Overview of the Seaside Schools and their connection to the Two Teachers study RCT}

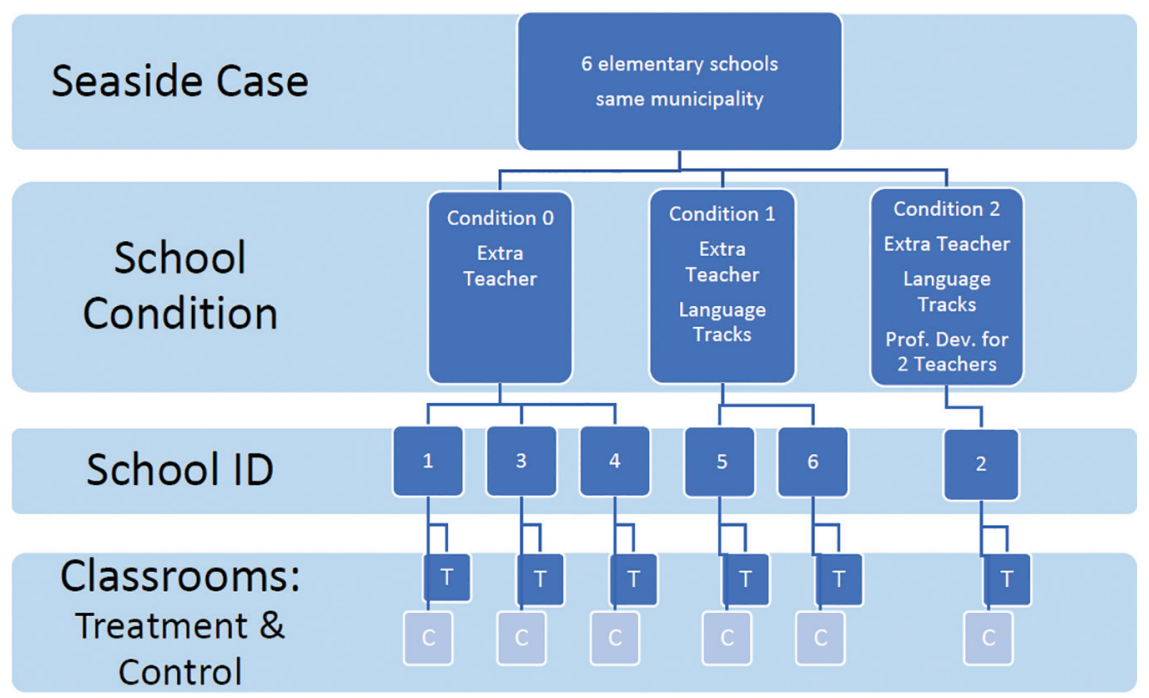

\section{Appendix 3: Field notes, table format, Year 2}

\section{Researcher}

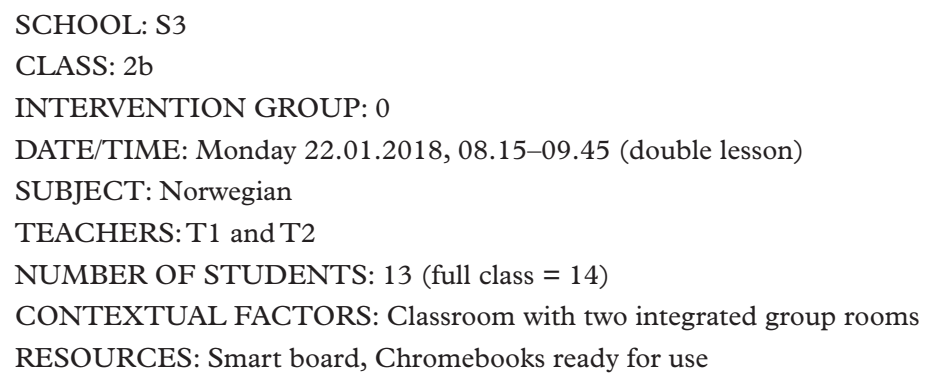




\section{A. K. H.Wagner, A. Skaftun E E. McTigue}

The example below shows one of seven events, occurring between 9.21 and 9.41.

\begin{tabular}{|l|l|l|l|}
\hline Event \\
\hline $\begin{array}{l}\text { Point in } \\
\text { Time }\end{array}$ & \multicolumn{2}{|l|}{9.21} \\
\hline \multicolumn{4}{|l|}{ Frames for teacher cooperation } \\
\hline $\begin{array}{l}\text { Both teachers } \\
\text { in the } \\
\text { classroom }\end{array}$ & $\begin{array}{l}\text { The teachers } \\
\text { split the class } \\
\text { between them }\end{array}$ & $\mathrm{x}$ \\
\hline $\begin{array}{l}\text { Organization of classroom } \\
\text { activities }\end{array}$ & $\mathrm{x}$ & Plenary & $\mathrm{x}$ \\
\hline Individual & Station & \\
\hline Pair & \multicolumn{3}{|l|}{} \\
\hline Group $\star \star$ & $\mathrm{x}$ & $\begin{array}{l}\text { Guided } \\
\text { writing }\end{array}$ & \\
\hline Type of activity & $\mathrm{x}$ & Student talk & \\
\hline Reading & $\mathrm{x}$ & Other & \\
\hline Writing & $\begin{array}{l}\text { Guided } \\
\text { reading }\end{array}$ \\
\hline
\end{tabular}

${ }^{\star}$ The teacher is the centre of the activity $\star \star$ The students work together in group

$\star \star *$ Reading in group guided by the teacher

$\star \star \star *$ Writing in group guided by the teacher

\section{Description}

T2 tells everyone that when they have finished [reading texts, on the Internet, about planets], they should enter the planets and write names on all the planets. They are told to find their headphones.

9.23: T2 tells 4 students to bring their reading homework book into the group room, with her. She asks them what they think this reading lesson is about? They talk about the pictures and what they are about. (Emotions.) Now let's read the pictures, says T2. Everyone should listen. T2 asks questions as they read, talks a lot (about being angry, sorry). Then they read out loud, together ("Maybe you shouldn't get angry because ..." [this is the main text of the lesson]). They talk about this text. Then T2 asks the students to look up new page. They talk about friendship, about apologizing. "This is what we are going to read!", says T2. Then the same procedure: They read one and one picture (with text) each, in turn, and T2 asks questions, engages (!) for discussion each time.

When this group has finished, T2 brings in a new group. Same procedure. While in the classroom, the students continue as before working on Chromebook.

9.36: 7 of the students in the classroom now work with their headphone on [i.e. have finished reading].

Only one student is in the group room with $\mathrm{T} 2$.

Inside the classroom, T1 makes sure that students with headphones are not just sitting with the same game.

\section{Interpretations, comments}

It seems to me that these are low performing students.

This is a going through the new reading lessons (guided reading).

Very fine session.

One second language student. What are the choices for selecting students for group sessions? Will there be it be an equal distribution over the week? (This is the first lesson, Monday.) I asked the teachers about this afterwards: They divide the students into 4 groups by level. In this lesson, the two lowest performing groups were taken out. The teachers say that they work with all 4 groups, but if there is little time, they will at least take out the two lowest performing. 


\section{Appendix 4: Narrative summary of the day}

\section{With a main focus on the L1 lessons, and the day as a background}

\author{
Part 1 \\ SCHOOL: S3 \\ CLASS: $2 \mathrm{~b}$ \\ INTERVENTION GROUP: 0 \\ DATE: Monday 22.01.2018 \\ TEACHERS: L1 and L2
}

Lesson 1+2: The day starts with double lesson, Norwegian. T1 and T2 are together in the classroom from the beginning, and during these first two lessons. They are very excited about being filmed and having sound recordings on - so am I. (T1 made it very clear the week before, when I came by to visit, that she did NOT look forward to this). (However, the day went very well, and both were proud of their own efforts.) The Smart board is on, and high-frequency words are read from the board: went, get, come, can, enter, again. Students come into the classroom (it has been snowing, and many therefore come in a little late), and go to their places, in a circle, in front of the classroom, looking at the blackboard (where the words are also written), repeating the words out loud. This is obviously a routine; instructions are not needed. (There is a high degree of discipline in all T1/T2s lessons (which is all lessons, except religion). Little time is wasted. But a warm and inclusive atmosphere. Positive discipline.) In the circle, they go through the schedule for the day, they sing ("Welcome to school"-song - a clear routine), the students pull the date and there is a whole procedure around this, and then they move on to the theme: the solar system, $\ldots$ the earth. They create mind maps together, sound out words together (clearly routine too). They spend about half an hour in the circle, before being told to "find the book" - which they do, and then go and sit at their desks (routine here too). They start individual work in this self-made book, about the planet Earth (they have made books on other planets before). They write sentences based on the mind map on the board. T1 goes around, helping. At the same time, T2 takes 4 students with her to the group room, draws the same mind map on the blackboard here, and starts the same activity as in the classroom. After a while, there is a small gathering in the classroom with demonstration of what to do on the Chromebooks, then the students return to their desks/group room to continue on the book/start with Chromebooks when they have finished the book. Now both teachers walk around and help. After a while of quiet work, all students store their books in the home-made folder hanging on the wall (where all self-made books are stored), and fetch Chromebooks. Now comes a session (individual, but allowed to get help from fellow students) where students work on questions from Chromebook/ workbook, then a subsequent session on Chromebooks with headphones. At this point, L2 takes the 4 students back into the group room, then another group, and works with the reading lesson. Finally, all the students in the classroom gather for a few minutes to tidy up, log off (while music is playing). They take a break, to play in the snow.

This double Norwegian lesson is characterized by very good organization, flexibility (teachers and groups in and out of group rooms), alternation between different tasks, calm (students work a lot individually), positive discipline (a lot of stars are given, see field notes), warmth, good atmosphere. 


\section{A. K. H. Wagner, A. Skaftun E E. McTigue}

Appendix 4: (Continued)

Lesson 3: Religion, taught by another teacher. The lesson begins with about 25 minutes of eating, while watching a documentary (The Family Expedition) on the Smart board. The religion lesson itself begins in circle, with simple singing ("The sun is good, the sun is the top ..."), then teacher-directed dramatization of the good Samaritan (more than half an hour). The teacher uses a lot of energy to calm the class - they are very undisciplined with this teacher. Finally, the students work individually (for about 12 minutes) on numbering pictures from the story in the correct order, including a 2-minute discussion at the end on which order is correct. T1 re-enters the classroom at the very end, walking around talking to individual students/helping/calming down. Then she puts on music, which signals that Maths now starts.

Lesson 4: Math, now follows without a break. T1 is the teacher. They begin in a circle, where $\mathrm{T} 1$ begins by rounding off the Samaritan theme, and then switches to the solar system and the seasons: their order, year, etc. Then she introduces Multi [the textbook], the chapter "Time", and then the students find their desks. Now follows a session where T1 asks questions ("Which month is first in the year?", etc.), and student after student gets to answer. Then everyone works individually in the book (writes the name of the season according to the picture). T1 goes around helping/watching. Finally, they find their homework for the next day, and comment on the dictation (words) to write at home. The lesson is concluded with everyone standing up and immediately starting the goodbye-song "Come on, now we put the school bag on ..." (clear routine). And T1 says that "the ticket for leaving the classroom is to tell me what month you have your birthday" (yippee, someone shouts). The school day finishes at 12.00 .

Part 2

Teacher co-operation

- Hierarchy

- Sharing of workload

- Integration

- Signs of common cooperation
The collaboration between $\mathrm{T} 1$ and T2 is very smooth. $\mathrm{T} 1$ is the clear classroom teacher. She manages the work in a circle (Norwegian lessons seem to begin with a gathering in circle), even though $\mathrm{T} 2$ also participates (and sometimes leads parts), and T1 is always the one staying in the classroom/whole group when there is individual work (as there is a lot of in this class), while T2 is always the one who takes out small groups (3-4 students) in the group room (which is inside the classroom itself [with door always open]). Although $\mathrm{T} 1$ is the clear classroom teacher and T2 largely takes care of small groups, I still feel that they have an equal "status" and that they have equally important contributions and are equally respected by the students.

There is little waiting in this classroom. Students seem to know exactly what to do and get started right away. Everything seems very well organized - well planned in advance (but I did not get the opportunity to discuss this with the teachers). 


\begin{tabular}{|c|c|}
\hline $\begin{array}{l}\text { Oracy } \\
\text { Types of questions } \\
\text { - Challenges } \\
\text { - Follow-ups } \\
\text { - Responses } \\
-\ldots\end{array}$ & $\begin{array}{l}\text { There is more talk in the lessons than I observed during Year One. } \\
\text { Teachers ask a lot of questions (in plenary, circle), organize question } \\
\text { rounds (short answers from each student), they spend a lot of time in } \\
\text { circle (the teacher talks a lot then), they sing some songs (but these } \\
\text { are always the same, simple songs - which seem to have a disciplinary } \\
\text { function rather than a language learning/cultural function). The religion } \\
\text { lesson is also very oral, but it is primarily the teacher who speaks - the } \\
\text { students are extras in the almost wordless dramatization of The Good } \\
\text { Samaritan. They also do oral assignments, though usually with one-word } \\
\text { answers from the students ("April"). } \\
\text { Little conversation. No conversations in group/pair. } \\
\text { The exception is the guided reading session with T2, here there is a little } \\
\text { more conversation. }\end{array}$ \\
\hline $\begin{array}{l}\text { Reading activities taking place } \\
\text { - Teacher's reading for the } \\
\text { class } \\
\text { - Students' own reading } \\
\text { - Going through reading } \\
\text { lesson } \\
-\ldots\end{array}$ & $\begin{array}{l}\text { T2 does guided reading with the groups she takes out in the group room. } \\
\text { There is a little loud reading from the teacher (single words), and the } \\
\text { students repeat in chorus, but there is no loud reading of coherent text. } \\
\text { Loud reading of homework is done once (when T2 takes out two groups). } \\
\text { These were the two lowest performing groups. } \\
\text { Otherwise there is mostly writing (Norwegian + a little in Maths) during } \\
\text { individual seat work, little focus on reading this day (no reading of } \\
\text { coherent text/of small books). }\end{array}$ \\
\hline $\begin{array}{l}\text { Writing activities taking place } \\
\text { - fill-in tasks } \\
\text { - letter formation practice } \\
\text { - individual text writing } \\
-\ldots\end{array}$ & $\begin{array}{l}\text { There is writing during individual seat work, in Norwegian lessons. } \\
\text { Booklets. (And a bit also in Maths.) They write in small home-made } \\
\text { books (which they also draw and colour to make nicely presented). The } \\
\text { students have made many such books, about different themes (see the } \\
\text { field notes). They seem to write a lot - in many subjects. This day, they } \\
\text { wrote sentences based on mind maps they made together in a circle, and } \\
\text { they wrote answers to questions. } \\
\text { There is no free writing or personal stories this day. No letter formation } \\
\text { practice. }\end{array}$ \\
\hline $\begin{array}{l}\text { Digital technology being used } \\
\text { - type of technology (tablets, } \\
\text { boards, computers ...) } \\
\text { - How technology is used } \\
\text { (in reading, in writing; apps; } \\
\text { products from publishers ...) } \\
\text { - Organization (individual, } \\
\text { in computer room; class } \\
\text { collection ...) } \\
\text { - practical challenges } \\
\text { (noise, technical difficulties, } \\
\text { teacher-student) }\end{array}$ & $\begin{array}{l}\text { Digital technology is used in Norwegian (+ eating) this day. } \\
\text { The Smart board is used a lot, both during dead time (for word reading } \\
\text { when students enter the classroom in the morning), during eating, } \\
\text { but also during lessons - to demonstrate e.g. Chromebook login for } \\
\text { everyone). } \\
\text { They often do tasks on Chromebooks - this is often the last task, a kind of } \\
\text { reward for having reached through the list of reading/writing tasks. } \\
\text { No use of tablets. } \\
\text { They use available textbook-related Internet resources. } \\
\text { Classroom collection with Chromebooks on trolley that the teachers roll } \\
\text { in and out of the classroom. There was one practical challenge with a } \\
\text { Smart board that didn't work (for a short while), otherwise everything } \\
\text { worked. }\end{array}$ \\
\hline
\end{tabular}

